\title{
José Carlos Mariátegui e a Tarefa Latino-Americana
}

\author{
José Carlos Mariátegui and the Latin American Task
}

Raphael Lana Seabra**)

\section{José Carlos Mariátegui e a tarefa latino-americana}

Resumo: O presente artigo é um esforço de refletir sobre os elementos que conferem unidade e coerência ao pensamento mariateguiano, da tarefa americana a que se propôs este intelectual peruano. Buscamos ir além de comentários exegéticos e centrados exclusivamente na questão indígena. Reconhecendo as dificuldades para a conformação de um mariateguismo, nosso interesse é demonstrar que ao colocar o conjunto de questões em termos da peruanização do marxismo, o cerne das preocupações mariateguianas extravasa as especificidades do país andino, indicando as possibilidades objetivas da revolução socialista em escala continental.

Palavras-chave: José Carlos Mariátegui. Mariateguismo. Revolução. América Latina.

\section{José Carlos Mariátegui and the Latin American task}

Abstract: The present article is an effort to reflect about the elements that grant unity and coherence to the mariateguian thought, the American task that this Peruvian intellectual had proposed. Therefore, we aim to go beyond the exegetical commentaries and focus exclusively on the indigenous issue. While recognizing the difficulties to the conformation of a mariateguismo, our concern are demonstrate that to place a set of issues in terms of the Peruvianization of the Marxism, the core of his consternations goes beyond the specificities of the Andean country, it indicates the objective possibilities for the socialist revolution on a continental scale.

Key-words: José Carlos Mariátegui. Mariateguismo. Revolution. Latin America.

(*) Doutor em Sociologia pela Universidade de Brasília, pesquisador do Grupo de Estudos e Pesquisa sobre o Trabalho da Universidade de Brasília (GEPT-UnB) e do Núcleo de Estudos Cubanos da Universidade de Brasília (NESCUBA-UnB). E-mail: <raphaelseabra@hotmail.com seabraraphael@gmail.com>. Recebidoem 09.09.2012 e aceito em 11.10.2012. 


\section{INTRODUÇÃo}

O historiador peruano Alberto Flores Galindo considerava que o mariateguismo era uma aventura duplamente incompleta, de um lado, pela própria especificidade do raciocínio de José Carlos Mariátegui, de outro, em razão do falecimento prematuro deste intelectual e as formas de apropriações de suas contribuições. Assim, conclui que o mariateguismo é antes de tudo um desafio para a esquerda peruana e latino-americana do que um sólido sustento ideológico. Nos últimos vinte anos, diversos movimentos populares de base indígena com característico histórico de lutas têm ganhado ampla visibilidade, tais como o Exército Zapatista de Libertação Nacional no México, a Confederação de Nacionalidades Indígenas do Equador e o Movimento Katarista e Cocalero na Bolívia. Mas, ao mesmo tempo, a adoção de uma estratégia política neodesenvolvimentista por alguns governos sul-americanos - a exemplo do Brasil - têm colocado o problema da terra em novas bases pela ação predatória da exploração dos recursos naturais. Portanto, dados os complexos processos políticos que se desenvolvem hoje na América Latina é imprescindível enfrentar tal desafio, do contrário, o mariateguismo permanecerá restrito aos exercícios de marxologia.

O presente artigo se insere no esforço de refletir as contribuições de José Carlos Mariátegui para além dos comentários elogiosos e/ou centrados exclusivamente na questão indígena presente no conjunto de sua obra, mas precisamente delineada nos Sete ensaios de interpretação da realidade peruana, senão que buscar os elementos que conferem unidade e coerência do pensamento mariateguiano, da tarefa americana a que se propôs este intelectual peruano. Nosso interesse central é demonstrar que, mesmo ao colocar o conjunto de questões em termos da peruanização do marxismo, o cerne das preocupações mariateguianas extravasa as especificidades do país andino, indicando as possibilidades objetivas da revolução socialista em escala continental.

O texto está dividido em três partes. Na primeira parte, buscamos sistematizar a unidade de pensamento e vida, que fazem de seu marxismo singular, mais do que um corpo doutrinário, uma verdadeira filosofia da práxis. Na segunda parte, indicamos as polêmicas travadas entre Mariátegui e a Internacional Comunista, como também a formação deturpada do mariateguismo no Peru. Na terceira e última parte, reconstruímos sua interpretação da realidade peruana, destacando suas contribuições mais originais para o marxismo latino-americano.

\section{O MARXismo agÔNico de Mariátegui}

Ao regressar ao Peru em 1923, após cerca de três anos e meio de estadia europeia, sobretudo na Itália, o intelectual era suficientemente lúcido sobre seu significado: "Fiz na Europa o melhor da minha aprendizagem. E acredito que não há salvação para a Indo-América sem a ciência e o pensamento europeus ou ocidentais." Esse período lhe proporcionou os instrumentos necessários para a tarefa autoimposta, claramente expressa em suas próprias palavras, "tenho uma ambição enérgica e declarada: a de contribuir para a criação do socialismo peruano" (MARIÁTEGUI, 2008: 32). Convencido de que a compreensão e o entendimento do valor e da questão indígena em seu tempo, só se 
efetivariam pela via - simultaneamente intelectual e prática — do socialismo, estava também ciente de que seu amadurecimento e consolidação em solo nacional só aconteceriam em meio aos embates peruanos. Dizer que suas concepções marxistas amadureceriam e se consolidariam em meio aos embates resulta da inexistência de organizações proletárias e sindicais, da tradição publicista marxista e de concepções acerca do socialismo, como bem observou José Aricó (1978), a atividade teórico-prática de Mariátegui foi antes fundacional do que dirigente.

Assim, as concepções marxistas mariateguianas foram desenvolvidas na linha de batalha, suas posições e definições amadureceram e se demarcaram em meio aos combates antioligárquicos, literários, indigenistas, anti-imperialistas e pela defesa do socialismo. Estes combates, numa entrevista publicada em 1926, o levaram a afirmar: "sou uma alma agônica, como diria Unamuno (Agonia, tal como Unamuno com muita razão observa, não é morte e, sim, luta. Aquele que combate agoniza)." (MARIÁTEGUI, 2005: 96-97.) A atribuição à Mariátegui de um marxismo agônico ${ }^{(1)}$ nos parece fundamental não necessariamente como indicação de uma fundamentação teórica e filosófica concluída, mas por sua peculiar capacidade revolucionária e sua ação político-organizativa (FLORES GALINDO, 1982; ESCORSIM, 2006).

A compreensão de seu marxismo agônico tem de levar em conta três questões indispensáveis. Em primeiro lugar, as específicas interpelações que a realidade exigia de Mariátegui: o confronto com o problema indígena que desde a Conquista era tratado como um problema moral, administrativo, étnico e/ou educacional, quando para Mariátegui claro estava que se tratava de um problema econômico, mais especificamente do problema da terra; o confronto com a "geração dos 900" que, embora tenha se caracterizado por seu interesse no estudo dos problemas peruanos e por sua busca de soluções capazes de alcançar o progresso, não rompeu com as premissas positivistas "do 'Progresso', a 'Ciência', a 'Razão', [que lhes] serviriam para justificar o crescente domínio do capital sobre a sociedade peruana, o papel dirigente da oligarquia 'ilustrada' e a subordinação e exclusão dos camponeses índios" (GERMANÁ, 1995: 59); a imperiosidade de estabelecer uma posição política, ideológica e organizativa socialista no contexto do surgimento do movimento anti-imperialista policlassista liderado por Raúl Haya de la Torre da Aliança Popular Revolucionária Americana (APRA) e a defesa da autonomia organizativa do Partido Socialista Peruano diante das diretrizes da Internacional Comunista para a América Latina; a interpretação dos processos revolucionários russos, chineses e mexicanos, prenhes de lições e exemplos para a problemática político-revolucionária peruana, como também a ascensão da contrarrevolução fascista na Europa.

Em segundo lugar, o fato de inexistir no Peru uma tradição organizativa proletária, círculos intelectuais e políticos de debate e difusão do socialismo: tal inexistência exige demasiado esforço, de maneira que Mariátegui se lança ao "estabelecimento de uma casa editora, a direção de Amauta, a criação de Labor, a animação do movimento operário-

(1) Sua interpretação sobre a condição agônica é formulada num comentário sobre A agonia do cristianismo, de Miguel de Unamuno, onde a "agonia não é prelúdio da morte, não é conclusão da vida. Agonia - como Unamuno escreve na introdução de seu livro - quer dizer 'luta'. Agoniza aquele que vive lutando — lutando contra a própria vida. E contra a morte" (MARIÁTEGUI, 2006: 177). 
-sindical, a fundação do partido e da central sindical - e os estudos, as investigações, as matérias para revistas e jornais" (ESCORSIM, 2006: 121). Portanto, o vazio teórico-organizativo e o excesso de atividades concentradas num mesmo indivíduo não lhe permitem grandes sistematizações, com exceção do clássico Sete ensaios sobre a realidade peruana. O ensaísmo foi o meio que permitiu a este intelectual intervir em diversos domínios do cenário político, econômico e cultural, como, também, um exercício de observação da vida cotidiana, uma ocasião para refletir sobre os acontecimentos e conectar aspectos da cena nacional à cena internacional e vice-versa. Por outro lado, o ensaísmo mariateguiano responde também aos limites impostos por seu autodidatismo, donde as exigências acadêmicas passam ao largo, daí as citações imprecisas, em alguns casos, a disposição inadequada do marco teórico e apropriação de ideias alheias (FLORES GALINDO, 1982: 59).

Em terceiro e último lugar, a conjugação dos elementos anteriores aponta sua relação peculiar com a teoria. Acreditamos que os fatos elencados acima, muito provavelmente, levaram o autor dos Sete ensaios... à concepção de que o que fez do marxismo uma força social cada vez maior "não foram os pedantes professores alemães da teoria da mais-valia, incapazes de acrescentar qualquer coisa à doutrina, só dedicados a limitá-la, a estereotipá-la; foram, antes, os revolucionários tachados de heresia" (MARIÁTEGUI, 2005: 179). Em relativa confluência com Georg Lukács ${ }^{(2)}$ (2001), para Mariátegui, a ortodoxia marxista, não se baseava simplesmente na "fé" e, tampouco, na "exegese" das teses marxianas, senão que o marxismo é:

"um método que se apóia inteiramente na realidade, nos fatos. Não é, como alguns erroneamente supõem, um corpo de princípios de consequências rígidas, iguais para todos os climas históricos e todas as latitudes sociais. Marx extraiu seu método das próprias entranhas da história. O marxismo, em cada país, em cada povo, opera e atua sobre o ambiente, sobre o meio, sem descuidar de nenhuma das suas modalidades." (MARIÁTEGUI, 2005: 103-104.)

Por considerar o marxismo como método que conduz inevitavelmente à práxis revolucionária e, junto a isso, pensar que entre o marxismo e o pensamento crítico existisse uma indispensável confluência, altamente criativa e renovadora ${ }^{(3)}$, Mariátegui foi capaz de apreender corretamente a dialética entre o universal e o específico, entre forma e conteúdo e, a partir daí, conceber o socialismo indo-americano. Adolfo Sánchez Vásquez (1998:50) destaca dois elementos essenciais do marxismo mariateguiano, capazes de sintetizar o discutido até aqui: "1. Sua atenção ao papel da ação, das forças sociais que podem transformar a realidade e 2 . Sua preocupação pelas peculiaridades desta realidade concreta, que devem ser, sobretudo, levadas em conta tanto na hora de sua interpretação quanto na de sua transformação prática, efetiva."

(2) Segundo Lukács (2001: 64,68), "o marxismo ortodoxo não significa, portanto, um reconhecimento sem crítica dos resultados da investigação de Marx, não significa uma 'fé' numa ou outra tese, nem a exegese de um livro 'sagrado'. Em matéria de marxismo, a ortodoxia se refere antes e exclusivamente ao método". Daí o filósofo húngaro conclui que "para o método dialético a transformação da realidade constitui o problema central".

(3) Há de se levar em conta que outra fonte de originalidade mariateguiana resulta de que os textos dedicados por Marx à discussão histórica, em sua maioria, foram publicados pouco após sua morte e difundidos anos depois. 
Michael Löwy está de acordo que Mariátegui considerava a consolidação do projeto socialista peruano como agonia permanente, como luta contínua "contra o tradicionalismo conservador da oligarquia, o romantismo retrógado das elites e a nostalgia do período colonial, [onde] ele apela a uma tradição mais antiga e mais profunda: a das civilizações indígenas pré-colombianas". De tal maneira que, para este intelectual brasileiro, o emprego do termo agônico de Miguel de Unamuno e do Mito de Georges Sorel sugere que "no coração da heresia mariateguista, da singularidade de sua interpretação do marxismo, encontra-se um núcleo irredutivelmente romântico"(4) (LÖWY, 2005: 8).

De fato, há elementos de protesto à mecanização do mundo, de apelo à fé e ao heroísmo revolucionários, como também às tradições comunitárias do campesinato indígena. São elementos que do ponto de vista imediato compõem, sem sombra de dúvida, valores ou imagens do passado pré-capitalista, apropriadas em tom de recusa à modernidade, ao industrialismo e ao capitalismo. Resgatar o mundo agrário e comunitário indígena, seus mitos e ser avesso ao progresso isolado dos setores econômicos mais dinâmicos do país em detrimento da satisfação das necessidades elementares da maioria da população, não se traduz em passadismo ou romantismo revolucionário. Nos Princípios programáticos do Partido Socialista, está muito claro o significado concreto do reavivamento e apropriação socialista da tradição andina:

"não significa absolutamente uma romântica e anti-histórica tendência de reconstrução ou ressurreição do socialismo inca, que correspondeu a condições históricas completamente superadas e do qual só restam, como fator aproveitável dentre de uma técnica de produção perfeitamente científica, os hábitos de cooperação e socialismo dos camponeses indígenas. $O$ socialismo pressupõe a técnica, a ciência, a etapa capitalista e não pode implicar o menor retrocesso na aquisição das conquistas da civilização moderna, mas, pelo contrário, a máxima e metódica aceleração da incorporação destas conquistas à vida social." (MARIÁTEGUI, 2005: 123-124 - itálico nosso.)

Deste prisma, nos parece excessivo condensar as concepções do marxismo mariateguiano dentro da tradição romântica. A crítica à civilização capitalista não se restringe à pura recusa, mas considera a passagem ao socialismo como negação, conservação e superação da etapa precedente.

Se o marxismo agônico, o marxismo definido e delimitado na frente de batalha nos surge efetivamente como legítima criação heroica, nos parece também que neste estão todas as consequências dos disparates cometidos em nome do que julgava seu pensamento. Tal maneira de refletir, posicionar e escrever sobre a realidade não admitia a ideia de um ponto final ou de uma conclusão, senão que lhe exigia o debate ininterrupto com história. De igual modo, sua morte veio a cortar sua trajetória no momento em que deveria afrontar os desafios mais complexos, provenientes da crise econômica que assolaria o país nos anos 1930, a necessidade de prosseguir a delimitação com o aprismo, sem ser

(4) Löwy (2005:9) apresenta o romantismo como "o protesto cultural contra a civilização capitalista moderna em nome de valores ou imagens do passado pré-capitalista - uma visão do mundo complexa e heterogênea, que se desenvolve a partir de Jean-Jacques Rousseau e chega até nossos dias -, está presente no próprio pensamento de Marx e na obra de autores marxistas importantes". 
absorvido pelas diretrizes da Internacional Comunista. Por tais razões, Alberto Flores Galindo (1982: 156) afirma que "o mariateguismo é mais um desafio para a esquerda peruana [e latino-americana] que um sólido sustento ideológico". Em resumo, um marxismo concebido em movimento, em combate ou em agonia e sua morte prematura, em pleno amadurecimento e quando os desafios se tornavam maiores, vem a interromper abruptamente as possibilidades do projeto mariateguiano, como também coloca grandes dificuldades para a conversão deste projeto numa forma de mariateguismo.

\section{A obra mariateguiana entre a DesqualificaÇÃo e a ADEQUaÇão: o Mariateguismo}

Ainda em vida, são muito conhecidas as relações polêmicas travadas entre o intelectual peruano e a Internacional Comunista. Destacamos três pontos polêmicos fundamentais entre a concepção marxista mariateguiana e a concepção marxista soviética: 1) segundo a Internacional, havia duas classes fundamentais antagônicas, o proletariado e a burguesia, onde caberia ao primeiro levar a cabo a revolução, assim a defesa de uma definição de classe baseada nas especificidades nacionais, culturais, étnicas e históricas, dando aos camponeses e indígenas importância decisiva junto ao operariado na condução da revolução lhe renderia a insígnia de intelectual pequeno-burguês, por romper com os esquemas de imposição ou sobreposição da classe operária sobre o restante da sociedade; 2) as discrepâncias sobre o tratamento do fenômeno imperialista e a natureza da revolução; para a Internacional, a revolução generalizada para os países coloniais e semicoloniais seria por excelência a revolução por etapas e o bloco de quatro classes - proletariado, campesinato, pequena-burguesia e burguesia nacional - concretizando a etapa nacional-democrática (ou anti-imperialista), uma vez que as condições não estariam "amadurecidas" para uma revolução socialista; ao contrário para Mariátegui, por causa das condições específicas de desenvolvimento capitalista na etapa do capital monopolista, não se podia estabelecer uma diferença entre os interesses do capital nacional e capital estrangeiro, pois ambos estavam indissoluvelmente unidos. Logo, o desenvolvimento capitalista peruano implicava diretamente no aprofundamento da dominação imperialista, resultando cada vez em mais subordinação, atraso e destruição das peculiaridades nacionais, portanto, o enfrentamento do imperialismo colocava como imperativo o enfrentamento do capitalismo dentro das fronteiras nacionais, conferindo a natureza socialista da revolução; 3) também, o nome Partido Socialista Peruano ia contra as determinações da III Internacional em abolir o nome socialista, identificado com o reformismo pequeno-burguês, determinando sua substituição por comunista. A Internacional exigia na América Latina a construção de partidos monolíticos, operários, disciplinados e centralizados; partindo da realidade peruana, Mariátegui defendia uma concepção particular das alianças de classe, o partido como organismo político de operários, camponeses e intelectuais, como também defendia que seu processo de construção deveria ser resultado da ação de grupos de base nos distintos centros do país (ARICÓ, 1978).

A questão é que tais polêmicas após o falecimento precoce do intelectual peruano forneceram o instrumental para a desqualificação e redução do alcance de sua contribuição para a construção do marxismo no subcontinente. A primeira fonte de críticas 
ao seu estilo de reflexão inicia-se pelo juízo formado pelo dirigente comunista argentino Vittorio Codovilla sobre os Sete ensaios de interpretação da realidade peruana presenteado por Hugo Pesce durante I Conferência Comunista Latino-Americana em julho de 1929. O primeiro ponto de seu juízo diz respeito ao ensaio, uma vez que este implicava no estilo típico de autores burgueses e reacionários, além do caráter provisório das afirmações. "Os ensaios ficavam para os intelectuais", e para os comunistas da Internacional "todos os intelectuais eram perigosos, porque se, todavia, não eram traidores, acabariam sendo"; o segundo ponto cairia sobre a concepção de uma realidade nacional específica, o que parecia absurdo para Codovilla, uma vez que para a Internacional existiam os países coloniais e semicoloniais, definidos pela relação específica com o capital imperialista. Dada a condição peruana de país semicolonial, não haveria motivos para se pensar traços distintivos de sua realidade nacional, não haveria porque diferenciá-la da Argentina, México ou Brasil (FLORES GALINDO, 1982: 27-28).

A aversão de Codovilla às concepções mariateguianas se generalizaria pouco depois por todo subcontinente pela linha oficial da Internacional. Tanto o foi, que seguindo fielmente as diretrizes de Moscou cerca de um mês após a morte de Mariátegui em 1930 o Partido Socialista Peruano foi transformado em Partido Comunista Peruano. Desde então, o "mariateguismo" é convertido numa "palavra acunhada para designar um desvio pequeno-burguês, uma sorte de 'aprismo de esquerda'" (ARICÓ, 1978: XXVIII), portanto, "mais que um passado a conservar ou desenvolver, o mariateguismo era definido como um lastro que era indispensável desfazer-se para avançar" (FLORES GALINDO, 1982: 147).

A primeira operação de apropriação do pensamento de Mariátegui foi realizada por um número de homenagem póstuma dedicada pela revista argentina Claridad. Dois militantes da APRA e vinculados estreitamente à Mariátegui, Manuel A. Seoane e Luis E. Heysen, buscam fazer um balanço crítico de seu pensamento. É interessante que ambos coincidem no resgate de seus valores intelectuais e morais, mas o desqualificam politicamente: "lacerado entre uma formação romântica que o arrastava com fanatismo cego a batalhar uma revolução irrealizável, e uma vocação para a ação política, a que sua sensibilidade de 'artista' antepunha barreiras impossíveis de superar" (ARICÓ, 1978: XXIV-XXV). O balanço crítico da APRA o converte num pensador romantizado, distante da ação política concreta, o associam à tarefa intelectual e moral empreendida anteriormente por Manuel González Prada ${ }^{(5)}$. Por fim, a pretensão era converter Mariátegui num antecedente próximo e direto da APRA, o que implicava necessariamente a desqualificação ou silenciamento a respeito de suas concepções teóricas e práticas ao redor do processo peruano e latino-americano (idem, ibidem).

A nova atitude de reconhecimento do pensamento mariateguiano só viria em 1946, pelo livro Mariátegui y su obra ${ }^{(6)}$ de Jorge del Prado. Desde então, gradualmente, Mariá-

(5) Poeta e ensaísta, primeiro divulgador do anarquismo no Peru, tendo exercido enorme influência sobre a jovem intelectualidade peruana na primeira década do século XX. É um dos primeiros intelectuais a desfazer-se do exotismo romântico indigenista e demonstrar a realidade indígena como elemento fundamental da sociedade peruana.

(6) De acordo com José Aricó (1978) e Alberto Flores Galindo (1982), a reivindicação do pensamento de Mariátegui nessa obra se direcionava a defender que seu marxismo e seu nacionalismo coincidiam pontualmente com os de Stálin. 
tegui começa a adentrar o rol do pensamento moderno peruano. "A obra de Mariátegui foi criando um amplo consenso, um público que espontaneamente se foi incrementando ao ritmo das edições populares dos Sete ensaios, A alma matinal ou Defesa do Marxismo" (FLORES GALINDO, 1982: 148). O consenso sobre a importância de sua obra não foi suficiente para eliminar a posição ambígua do reconhecimento de seu pensamento. Assim, como um dos precursores da tradição intelectual peruana, é tornado ícone imprescindível do patrimônio cultural peruano, muito embora esvaziado e distanciado de qualquer perspectiva crítica e/ou revolucionária.

A questão da formação do mariateguismo se torna ainda mais complexa quando a esquerda peruana aumenta e se diversifica em várias tendências que, não somente consideram imprescindível partir de Mariátegui, como também edificar uma imagem adequada de seu pensamento. Deparamo-nos na década de 1960, como sugere Flores Galindo (ibidem: 149), com várias imagens do Mariátegui "trotskista, maoísta, inconcluso 'gramsciano' e também precursor do 'eurocomunismo". O traço comum de todas estas "reivindicações" é que a aceitação e difusão do pensamento mariateguiano só é de fato concretizada mediante alterações, anexações e submissões de seu raciocínio a outros referenciais teóricos que melhor acomodavam a fundamentação ou legitimação da ação partidária, reduzindo drasticamente seus aspectos de leitura original da realidade peruana a simples voos desajeitados de um aprendiz do marxismo. Em síntese, tanto seu reconhecimento como precursor da tradição intelectual peruana, como edificação mais adequada de seu pensamento pela esquerda, procedem de maneira semelhante ao período stalinista.

\section{A unidade de Reflexão do pensamento mariateguiano: o Socialismo indo- -AMERICANO E A NATUREZA DA REVOLUÇÃO LATINO-AMERICANA}

Como vimos anteriormente, a relação específica de Mariátegui com a teoria marxista e sua confluência com o pensamento crítico, lhe conferiu uma capacidade altamente criativa e renovadora. Isso permitiu ao nosso autor escapar a duas tentações opostas que ameaçavam a construção do marxismo latino-americano: tanto ao excepcionalismo indo-americano, que "tende a absolutizar a especificidade da América Latina e de sua cultura, história ou estrutura social. Levado às suas últimas conseqüências, esse particularismo americano acaba por colocar em questão o próprio marxismo como teoria exclusivamente européia"; como também, eurocentrismo "que se limita a transplantar mecanicamente para a América Latina os modelos de desenvolvimento socioeconômico que explicam a evolução histórica da Europa ao longo do século XIX" (LÖWY, 2006: 10).

A concepção mariateguiana do socialismo indo-americano trata-se, sem sombra de dúvida, do primeiro esforço de definir em termos marxistas a realidade nacional. Esse esforço, ou ensaio de interpretação da realidade, não se propunha nem a superar o pensamento europeu baseado numa espécie de fé do porvir latino-americano, subcontinente eleito para ser o futuro da civilização, como também não almejava acelerar o amadurecimento das condições econômicas e sociais, logo do capitalismo peruano, como meio de realizar a etapa nacional-democrática. Sua interpretação crítica da realidade é suficientemente clara, ao afirmar que o drama do Peru contemporâneo nasce "do 
pecado da Conquista. Do pecado original, transmitido à República, de querer constituir uma sociedade e uma economia peruana 'sem o índio e contra o índio"' (MARIÁTEGUI, 2005: 92). Em síntese, a República seguia ignorando a existência das grandes massas de indígenas, camponeses e arrendatários e, nesse sentido, dava continuidade às estruturas de propriedade, produção e exportação anteriores.

O esgotamento da exploração das minas de ouro e prata no interior converte o guano e o salitre na principal fonte de renda fiscal da República. O grande destino das exportações destas substâncias era a Inglaterra que, desde então, passou a investir pesadamente na construção de ferrovias e outros serviços para melhorar a extração e comercialização (SICILIA, 2007). A construção da infraestrutura em torno deste comércio era garantida por meio da hipoteca da exploração do guano e salitre. A Guerra do Pacífico (1879-1883), na qual o Peru perdeu completamente os territórios do salitre e a maior parte dos referentes ao guano, então cobiçados pelo Chile, coloca a questão nacional como ponto obrigatório de partida para toda a reflexão sobre a possibilidade de um projeto de transformação da sociedade peruana. Todo o ônus do conflito e da reconstrução política e econômica recai sobre as amplas massas de camponeses indígenas, mineiros, estudantes universitários e do nascente operariado urbano peruano.

Sobre o plano da história mundial, a independência latino-americana e as fontes de comércio que se abrem às jovens repúblicas se apresentam como decididas "pelas necessidades de desenvolvimento da civilização ocidental ou, melhor dito, capitalista. (...) Procuraram no tráfico com o capital e a indústria do Ocidente os elementos e as relações exigidas pelo incremento de suas economias. Começaram a enviar ao Ocidente capitalista os produtos de seu solo e seu subsolo. E do Ocidente capitalista começaram a receber tecidos, máquinas e mil produtos industriais." (MARIÁTEGUI, 2008: 37-38). Mariátegui sustenta a ideia de que o período dominado e caracterizado pelo comércio do guano e do salitre demarca o primeiro impulso enérgico do capitalismo peruano. Mas é da crise pós-bélica que o "capitalismo formal" se desenvolve em bases mais sólidas, dado que o país é reorganizado economicamente em total conformidade com os interesses das classes capitalistas nacional e imperialistas.

O autor de Sete ensaios apresenta uma definição esquemática de alguns traços essenciais da formação e do desenvolvimento da economia peruana deste novo período. Da reorganização econômica, estabelecem-se fábricas, usinas, transportes e começa a se formar o proletariado industrial, ainda que restrito ao litoral do país; o surgimento de bancos nacionais e bancos estrangeiros, conferindo grande importância ao capital financeiro; o aquecimento do comércio no Pacífico sul-americano em razão da abertura do Canal do Panamá; a gradual superação do poder britânico pelo poder estadunidense; o desenvolvimento de uma classe capitalista, distinta dos moldes aristocráticos; a ilusão da borracha; a melhora nos preços internacionais do setor exportador provoca o rápido crescimento da fortuna nacional; e a reabertura de créditos estrangeiros levou o Estado a recorrer a empréstimos para a execução de seu programa de obras públicas (idem, ibidem: 44-45).

O advento da Primeira Guerra tem peso fundamental neste processo, e embora brinde as classes dominantes com grandes lucros, internamente essa bonança comercial 
reflete negativamente no custo de vida das classes populares. Assim, mesmo que haja o incremento da produção e da demanda de produtos como o petróleo e derivados e o cobre, como também o incipiente desenvolvimento da indústria têxtil e de transportes, o Peru ainda mantém caráter de país agrícola, cujos principais produtos exportados são algodão, açúcar, lã e couro. O caráter agrícola peruano significa que "o cultivo da terra ocupa a grande maioria da população nacional. $\mathrm{O}$ índio, que representa $4 / 5$ da população, é habitualmente agricultor tradicional". Segundo Mariátegui, "esse sistema econômico manteve, na agricultura, uma organização semifeudal, que se constitui na maior dificuldade para o desenvolvimento do país" (idem, 2008: 46-47). Antes de avançar, é necessário definir o entendimento sobre feudalidade e semifeudalidade, conceitos tão recorrentes na obra mariateguiana. Antes de sugerir qualquer transferência esquemática de interpretações europeias, este autor adverte que:

"a sobrevivência da feudalidade não deve ser buscada, certamente, na subsistência de instituições e formas políticas ou jurídicas da ordem feudal. Formalmente, o Peru é um Estado republicano e democrático-burguês. A feudalidade ou a semifeudalidade sobrevive na estrutura da nossa economia agrária. E, por ser o Peru um país predominantemente agrícola, as condições da sua economia agrária refletem-se de modo decisivo na prática e nas instituições políticas" (MARIÁTEGUI, 2005: 145.)

Assim, a feudalidade ou semifeudalidade é definida em relação com a predominância latifundiária na economia nacional. Portanto, esta organização específica da agricultura controlada pelos gamonales ${ }^{(7)}$ se apresenta como entrave para o desenvolvimento capitalista real, uma vez que o regime de assalariamento avançava muito lentamente no país, dado o sistema de trabalho empregado nesses latifúndios, por meio do enganche ${ }^{(8)}$ e da yanaconagem ${ }^{(9)}$.

As considerações acerca deste esquema de evolução econômica levam Mariátegui a concluir que no Peru, "um capitalismo formal já está estabelecido" (idem, 2005: 147). A forma específica da integração ao mercado mundial impõe à América Latina papel coadjuvante no desenvolvimento do capitalismo central e o grosso de sua economia é realizado no mercado externo; a penetração imperialista na economia peruana, ditando quais seriam os setores mais dinâmicos em conformidade com seus interesses e, logo o crescente caráter monopolista adquirido por este capital ao controlar ramos inteiros da

(7) Sua especificidade está em considerar "praticamente seu latifúndio como fora do poder do Estado, sem a menor preocupação com os direitos civis da população que vive dentro dos confins de sua propriedade. Cobra impostos municipais, outorga monopólios, estabelece sanções sempre contrárias à liberdade dos braceiros e de suas famílias. Os transportes, os comércios e até os costumes estão sujeitos ao controle do proprietário dentro da fazenda" (MARIÁTEGUi, 2008: 101).

(8) E um sistema de recrutamento e sujeição da mão de obra por meio da dívida ou da imposição de condições de trabalho, extremamente desfavorável a parceiros, além da proibição expressa de qualquer organização autônoma por parte dos camponeses.

(9) O trabalhador agrícola é encarregado de uma pequena parcela de terra com a obrigação de trabalhar em regime de parceria com o gamonal, além de dever algumas obrigações pessoais. 
economia $^{(10)}$ não colocava a consolidação do regime de assalariamento e do mercado interno como objetivos nem do capital imperialista, nem do capital nacional, senão que reduzir os custos de produção das importações para o primeiro, e garantir um patamar médio da taxa de lucro do segundo. A formalidade capitalista resulta, sobretudo, do caráter dirigente do imperialismo sobre o conjunto da economia, cujos interesses coincidiam com os das classes dominantes peruanas, sobretudo os grandes latifundiários ou gamonales $^{(11)}$.

Esta interpretação da realidade peruana o leva a colocar o problema indígena em novas bases, recusando a apresentação deste como questão pedagógica, moral, administrativa e/ou étnica. Assim, Mariátegui defende que "a questão indígena nasce de nossa economia. Tem suas raízes no regime de propriedade da terra". As questões que envolvem 4/5 da população peruana não são extrassociais; portanto, "qualquer tentativa de resolvê-la com medidas de administração ou polícia, com métodos de ensino ou obras de estradas, constitui um trabalho superficial ou adjetivo, enquanto subsistir o feudalismo dos gamonales" (idem, ibdem: 53). E se o socialismo direciona nosso autor a essa colocação do problema indígena em novas bases, não resta dúvida de que "seus realizadores devem ser os próprios índios. Essa concepção leva a ver na reunião dos congressos indígenas um feito histórico" (idem, ibdem: 65).

O elemento que, segundo a concepção indo-socialista mariateguiana, faz dos indígenas os próprios realizadores de um novo projeto nacional é a permanência — apesar de todos os percalços do Império Inca e das violências da Conquista e da República -, de formas de propriedade coletiva da terra e da organização comunitária do trabalho. A sobrevivência e permanência do ayllu — subsistente em estruturas concretas e no profundo espírito coletivista - "reunia condições favoráveis para que o comunismo agrário primitivo (...) transforme-se, sob a hegemonia da classe proletária, numa das bases mais sólidas da sociedade coletivista preconizada pelo comunismo marxista" (idem, 2005: 144).

A fim de evitar qualquer equívoco ou distorção, Mariátegui adverte que "o comunismo moderno é coisa distinta do comunismo incaico. (...) Pertencem a diferentes épocas históricas. Constituem a elaboração de civilizações diferenciadas. A dos incas foi uma civilização agrária. A de Marx e Sorel é uma civilização industrial. Naquela, o homem se submetia à natureza. Nesta, às vezes a natureza se submete ao homem" (idem, 2008: 91). Sendo assim, reiteramos que se a comunidade indígena representava em bases concretas a institucionalização de relações de propriedade e da divisão do trabalho distintas e antagônicas ao capitalismo, não há qualquer passadismo ou idealismo em tais afirmações.

(10) A título de exemplo, a exploração do cobre estava sob o controle da companhia estadunidense Cerro de Pasco Cooper Corporation, o petróleo era monopólio da Standard Oil e os engenhos açucareiros estavam sob controle da empresa alemã Casa Grande (SICILIA, 2007).

(11) A concepção de capitalismo formal de Mariátegui guarda estreita relação com a concepção de subsunção formal do trabalho ao capital de Karl Marx: "é normal que a subsunção do processo de trabalho no capital se opere com base num processo de trabalho preexistente, anterior a essa subsunção no capital e com uma configuração baseada em diversos processos de produção anteriores e outras condições de produção; o capital subsume em si determinado processo de trabalho existente, como, por exemplo, o trabalho artesanal ou o tipo de agricultura que corresponde à pequena economia camponesa autônoma." (MARX, 2004: 89.) 
Partindo da questão nacional, Mariátegui elenca todos os elementos que conferem especificidade ao capitalismo peruano. Vimos, portanto, que, desde a independência, as relações que a jovem república peruana estabelece com o capitalismo central a relegam à posição de economia primário-exportadora. Embora se forme uma burguesia comercial no Peru, o caráter capitalista primário-exportador e as bases da divisão internacional do trabalho se fundamentam na concentração da propriedade agrária. Assim, o escoamento majoritário de sua produção para o exterior e a concentração latifundiária da terra que reproduz formas não salariadas de produção ignoram a formação do mercado interno e em razão direta reforçam sua restrição.

Caracterizada a realidade peruana, nosso autor estabelece uma poderosa hipótese generalizável a todo o subcontinente de que "estamos na época dos monopólios, vale dizer, dos impérios. Os países latino-americanos chegam com atraso à concorrência capitalista. Os primeiros postos já estão definitivamente ocupados. O destino destes países, dentro da ordem capitalista, é o de simples colônia" (idem, 2005: 119-120). Deste ponto de vista, "nossos latifundiários, nossos fazendeiros, quaisquer que sejam as ilusões que tenham sobre sua independência, atuam na verdade como intermediários ou agentes do capitalismo estrangeiro" (idem, 2008: 109). A ausência de uma burguesia com sentido concretamente nacional e democrático, que antes disso, juntamente com os setores dominantes agrícolas mais retrógados "veem na cooperação com o imperialismo a melhor fonte de ganhos, sentem-se suficientemente donas do poder político para não se preocupar seriamente com a soberania nacional", o marxista peruano chegará à conclusão de que "a revolução latino-americana será uma etapa, uma fase da revolução mundial, nada mais, nada menos. Será, pura e simplesmente, a revolução socialista”. E, rejeitando qualquer forma de etapismo, reitera que "a esta palavra acrescentem, segundo os casos, todos os adjetivos que quiserem: 'anti-imperialista', 'agrarista', 'nacionalista-revolucionária'. O socialismo os supõe, os antecede, abrange-os a todos” (idem, 2005: 119 — itálico nosso).

A defesa da natureza socialista da revolução peruana o levará, inevitavelmente, a polêmicas e demarcação de posições em relação a outras correntes - já apresentadas anteriormente - , como a Apra e a Internacional Comunista. Naquele momento, o anti-imperialismo era a palavra de ordem de qualquer movimento que se pretendesse revolucionário e/ou comunista. Por isso mesmo, as polêmicas sobre a natureza da revolução serão travadas, em sua maioria, a partir do ponto de vista anti-imperialista.

Destacamos aqui dois pontos onde Mariátegui delimita sua posição sobre o anti-imperialismo e, simultaneamente, reafirma a natureza socialista da revolução: a) os limites da formulação única da tática anti-imperialista aos países semicoloniais, que embora subordinados ao imperialismo, não implicava na homogeneidade das realidades nacionais. Embora haja a cooperação entre as burguesias nacionais e as imperialistas, há de considerar-se que existem diferenças claras entre aquelas formalmente soberanas e aquelas sob intervenção e ocupação militar. Isso quer dizer que o anti-imperialismo não é, necessariamente, uma luta de libertação nacional em todas as nações semicoloniais; b) o retrocesso organizacional decorrente da redução da luta anti-imperialista a programa político, aqui não se trata de prescindir do elemento mobilizador do anti-imperialismo. A agitação destaca as notáveis expressões da presença do capital estrangeiro e seus me- 
canismos comerciais e financeiros de subordinação da nação. Mas, supondo-se que possa mobilizar o conjunto da sociedade contra a ingerência estrangeira - do operariado, campesinato, pequena burguesia à grande burguesia -, o anti-imperialismo não anula $o$ caráter antagônico das classes e tampouco as divergências de interesses entre elas. O enfrentamento do imperialismo demanda, definitivamente, romper com o sistema capitalista e todas as relações que o engendram (idem, ibidem).

\section{CONSIDERAÇÕES FinAis}

Podemos discordar sobre a terminologia e o tratamento analítico conferido à feudalidade ou semifeudalidade para considerações sobre a organização da colônia e da república. "No entanto, no plano analítico e explicativo suas observações e conclusões mostram-se corretas e encontram quase total corroboração nas investigações recentes" (FERNANDES, 2002: 37). Suas observações e conclusões sempre fundamentadas nas lutas de classes, nas especificidades do capitalismo nacional e suas relações com o capital imperialista e a natureza socialista da revolução, de nosso ponto de vista, antecipam algumas das contribuições da teoria marxista da dependência para a revolução continental. Por isso mesmo, o conjunto diversificado de questões suscitadas por Mariátegui na curta década de 1920, como o problema indígena, a questão agrária, o esquema de evolução econômica, a rapinagem imperialista e a natureza da revolução socialista, mesmo que em novas bases, ainda fornecem o referencial para o subcontinente, levando-se em conta as peculiaridades de cada realidade nacional.

Ao fornecer o referencial para se refletir sobre a América Latina, há de se ponderar sobre as diferenças entre nações indígenas que formam a maioria da população em países como o México, Peru, Guatemala ou Bolívia e as reduzidas tribos indígenas remanescentes em algumas regiões do Brasil. Para aqueles países de maioria indígena, destacam as lutas pela participação nas estruturas de poder, pela resistência cultural, pela reforma agrária e pela ênfase numa postura soberana e anti-imperialista; para países como o Brasil donde o genocídio dos povos originários foi altamente "eficaz", ganham destaque os combates travados contra formas de desenvolvimento e progresso civilizatórios altamente predatórios do ponto de vista social e ambiental, na redução das áreas de reserva indígena. Nota-se que, em ambos os casos, o indígena é colocado como problema da nação, como problema da terra, mas dentro das especificidades nacionais.

São raríssimas as menções ao Brasil nas obras do intelectual peruano, como também são notórias as diferenças da questão racial no Brasil, mesmo assim acreditamos que tais fatos não reduzem a potencial contribuição de Mariátegui para a reflexão da realidade brasileira. O que se coloca como problema da nação é não somente a resistência dos indígenas, mas também a resistência dos camponeses, ribeirinhos, remanescentes de quilombolas etc. à proliferação desenfreada e predatória do latifúndio, das mineradoras, da construção de hidrelétricas, da ação de madeireiras. Esse conjunto de resistências populares nos revela a permanência da centralidade do problema da terra em pleno século XXI.

Para o intelectual peruano, a missão digna das novas gerações era não permitir que o "socialismo seja na América decalque e cópia", senão que este "deve ser criação heroica" 
(MARIÁTEGUI, 2005: 120). Sublinhamos que estas novas gerações têm acertado na medida em que têm sido fiel a essa prédica, e ao contrário, têm tropeçado no caminho quando incorrido em decalque e cópia. Claro que não nos faltam tropeços por nossa própria conta, mas estes jamais serão impedimentos para fazer do socialismo criação inventiva, original e heróica (RETAMAR, 2003).

\section{ReFERÊNCIAS BibLIOGRÁFicAS}

ARICÓ, José. Introducción. In: (org.). Mariátegui y los orígenes del marxismo latinoamericano. Ciudad de México: Cuadernos Pasado y Presente, 1978.

ESCORSIM, Leila. Mariátegui: vida e obra. São Paulo: Expressão Popular, 2006.

FERNANDES, Florestan. Os Sete Ensaios. In: AMAYO, Enrique; SEGATTO, José Antonio. José Carlos Mariátegui e o marxismo na América Latina. Araraquara: Unesp, 2002.

FLORES GALINDO, Alberto. La agonia de Mariátegui: La Polémica con la Komintern. Lima: Centro de Estudios y Promoción de Desarrollo, 1982.

GERMANÁ, César. El "Socialismo Indo-Americano" de José Carlos Mariátegui: proyecto de reconstitución del sentido histórico de la sociedad peruana. Lima: Editora Amauta, 1995.

LÖWY, Michael. Introdução. In: MARIÁTEGUI, José Carlos. Por um socialismo indo-americano: ensaios escolhidos. Rio de Janeiro: Editora UFRJ, 2005.

O marxismo na América Latina. São Paulo: Perseu Abramo, 2006.

LUKÁCS, Georg. História e consciência de classe. São Paulo: Martins Fontes, 2001.

MARIÁTEGUI, José Carlos. Por um socialismo indo-americano: ensaios escolhidos. Rio de Janeiro: Editora UFRJ, 2005.

Sete ensaios de interpretação da realidade peruana. São Paulo: Expressão Popular; Clacso, 2008. MARX, Karl. Capítulo VI inédito de O Capital. São Paulo: Centauro, 2004.

RETAMAR, Roberto Fernández. Un siglo para el Amauta. In: RETAMAR, Roberto Fernández. Algunos usos de civilización y barbarie. La Habana: Letras Cubanas, 2003.

SANCHÉZ VÁSQUEZ, Adolfo. Mariátegui, grandeza e originalidade de um marxista latino-americano. In: PERICÁS, Luiz Bernardo, BARSOTTI, Paulo (orgs.). América Latina: história, idéias e revolução. São Paulo: Xamã, 1998.

SICILIA, Luis. José Carlos Mariátegui: un marxismo indígena. Buenos Aires: Capital Intelectual, 2007. 